\title{
Role-Play Kitchen - A Web Application
}

\author{
Karel Zdarek
}

\begin{abstract}
This paper introduces a web application designed primarily for language teachers to help them create and organize role-play and presents research results of the application testing in an educational setting. The work draws on the author's previous research on a technique called "Radio Role-Play", which uses the context of a fictional broadcast studio. Specifically, the idea for the app originated as an answer to certain limitations of the technique, mainly classroom organization aspects and the students' time management within the role. The qualitative research is intended to find out how students perceive and evaluate the use of technology (the web application on tablets and smartphones) in roleplaying, and how their role-playing experience might differ in comparison with non-digital (paper, oral) instruction. The application was tested with three groups of students aged 15-17 at Johannes Kepler Grammar School in Prague, Czech Republic, in May 2014. The data for this qualitative research were collected by means of an open questionnaire. The research findings are complemented with the teacher's/author's reflection in terms of the educational processes.
\end{abstract}

\section{Introduction}

This paper draws on the author's previous research on "Radio Role-Play", his own experience with role-playing, and how the introduced web application (henceforth referred to as app) helps resolve some of the students' and author's concerns specific to the author's particular approach to role-playing in language teaching (Zdarek 2013).

\subsection{What is Radio Role-Play?}

Radio Role-Play is an innovative, drama-based, language-teaching technique that uses a fictional radio studio and situational context to help students enter and explore content of language learning materials (mainly texts and recordings). Students work mostly in pairs or small groups and role-playing takes place simultaneously with no audience. The pre-text (O'Neill, 1995) is conveyed by means of the teacher's narration and tension or conflict is 
introduced by role-cards. Role-cards set the individual tasks for each of the roles and often generate conflict t o a c ertain e $\mathrm{x}$ tent. $\mathrm{T}$ he $\mathrm{w}$ ay $\mathrm{r}$ ole-cards are composed is similar to the short drama-communicative open-ended scenarios, a technique of strategic interaction by DiPietro (1982).

Apart from the general principles of educational drama, Radio Role-Play is based on the principles of task-based learning (Ellis, 2003). Radio Role-Play also integrates contextualized grammar and vocabulary (Dekeyser \& Sokalski 1996; Shrum \& Glisan 2000). In terms of procedure, the most common type of instruction is text work (reading, comprehension, vocabulary work) followed by a role-play, which provides students with an opportunity to practice the new language and speak within a meaningful and emotionally charged context.

\subsection{Why Role-Play Kitchen?}

The original title, Role-Play Factory, was meant to reflect o n e of th e main purposes of the app - a tool that would enable teachers to create, modify and facilitate role-playing in their language teaching. The name, however, seemed rather inappropriate for a drama based teaching technique due to its common connotations (tedious work, manufacture, etc.) and after some thought it was titled Role-Play Kitchen bearing more pleasant connotations of a place of creation, employment of imagination to suit individual taste, new recipes, experimentation, sampling, feasting and enjoyment. If large enough, it can also serve as a place where both experienced chefs and apprentices meet, share ideas, recipes and experience. The purpose of the proposed app is, therefore, twofold: firstly, a s m e ntioned a b ove, it s u pports $\mathrm{c} r$ eating a $\mathrm{n}$ d facilitating role-playing activities and, secondly, ideas for role-plays can be shared with language teachers worldwide within the web-based application.

Educational technology is used nowadays in various fields of education: army training, medicine, physical education, physical and mental rehabilitation and language teaching (de Freitas 2006; Hays 2005). There are many positive results from school environments. Educational technology (gaming and interactive applications) can increase students' motivation for learning (Barab et al. 2005; Kirriemuir \& McFarlane 2004), make the process of learning more effective and contribute to skills development (de Freitas 2006; Gee 2003; Squire 2005; Papastergiou 2009).

\subsection{Limitations of Radio Role-Play}

The idea for the role-playing app for language teaching originated from the limitations found in the author's previous research on the Radio RolePlay technique (Zdarek 2013). The conclusion of the qualitative study (a questionnaire with open questions and interviews) in a group of 13 high-school students indicated an increased level of engagement and motivation, increased student talking time, provided opportunities to activate new vocabulary and to be creative, reduced timidity to speak, and reduced fear of making mistakes. 
On the other hand, the students' answers addressed several limitations of the technique: 1) students' preferred textual material for a role-play in situational contexts; 2) pre-teaching and practicing vocabulary to be later contextualized within a role-play; 3) no or limited error correction; 4) importance of balancing role-playing and language work, particularly, focusing on grammar and vocabulary. Some of the students' concerns have been implemented in the process of refinement of the technique within the author's action research, namely, textual input and pre-teaching vocabulary. Absence of error correction during a speaking activity is a relevant concern and every teacher must assess the risk of having their students speak freely with limited error correction due to both significant increases in noise levels and to students' simultaneous pair or group work. Subscribing to the "fluency p r ecedes a c curacy" a p proach to language teaching (Brown 2001; Thornbury 1999), this is a risk one might be willing to take.

In addition to the points raised by the students, there were four major limitations on the author's part. 1) Paperwork: Role-plays in the author's educational setting are almost always tailor-made or adapted to suit the needs and proficiency level of each group of students. Therefore, each set of role-cards often needs to be printed and cut out. 2) Flexibility: Closely related to the preceding concern, each time a role-play is realized it requires thorough planning and a time-consuming process of creating or adjusting role-cards. 3) Classroom instruction: The process of instruction includes pre-text (O'Neill 1995) - a phase during which the situational context is introduced to students through narration, possibly including some of the dramatic tension related to the role-play the students are about to enter. Distributing role-cards is a necessary part of instruction which, although being relatively fast (30 seconds to one minute), can disrupt the atmosphere of expectation created by the narration. In single phase role-play this issue can be solved by distributing role-cards before introducing the pre-text. Some role-plays, however, comprise several phases, one following the other in a close succession, each with their own pre-text and set of role-cards. Consequently, changing the order or distribution of papers and narrating the pre-text will not be a solution. In brief, physical manipulation with role-cards appears to be an unwelcome intervention to the flow of the lesson.

Based on the research conclusions (Zdarek 2013) and the author's personal experience stated above, a question arose as to whether or not and how a digital tool might help solve some of these concerns. The question later took form as a simple web application which is presented in this paper.

\section{Role-Play Kitchen}

In terms of coding, the web app Role-Play Kitchen (Zdarek, 2014), is written in HTML code using CSS styles and one JavaScript function. There have been various attempts at defining a web a pplication and the proposed HTML, JavaScript and CSS code does not fulfil all the criteria of a web application 
definition; however, it does contain a simple function (the timer) and therefore it may technically be classified as one.

\subsection{Functionality of the app}

The app provides a list of role-plays which are available for immediate use or adaptation. Each student has his own device which displays the content in the web browser. The content is organized in a hierarchy of separate web pages which are interconnected and the user can navigate up and down 4 levels: main page - list of role-plays - particular role-play page - text / language work / role-play cards. On the particular role-play level the content includes texts to provide situational input, vocabulary lists and exercises (the exercises are not interactive in this pilot version) and a set of role-cards. On the role-card page there is a start and stop button; the start button starts the timer that counts down the amount of time set for the particular role-play. Above the start button there is a drop down menu titled "minutes", which enables the user to set the timer ( 1 to 10 minutes). The timer can be stopped by tapping on the stop button.

\subsection{Process of instruction}

The process of instruction (in principle) copies the "analog", one that uses printed texts, gap-filling t a sks a n d r o le-cards. The o n ly difference is that students access the learning content via their mobile devices (i.e. tablets, smartphones) and that the teacher's instruction includes tasks such as: open the article by tapping on the tab titled "text" instead of physically handing it out. The same applies to all the other printed material. The individual steps of class instruction will be explored below.

Choosing a role-play - The user chooses a particular role-play by tapping on its title in the list of role-plays which then directs the user to a new page with several navigation buttons: text, gap-fill and role-card buttons for each of the roles in the particular role-play (see Figure 1).

Working with the text and language content — The teacher instructs their students to open the texts (tap on the text tab) and read them. Subsequently, the teacher focuses on new vocabulary, elicits or explains the meaning of new lexical items and lets the students practice the use of the vocabulary in the series of activities (matching words with their definitions, $g$ ap-filling ex er cises). An alternative might be using the provided list of words to re-tell the content of the article by means of using the list of given words (in the order as they appeared in the text). This should familiarize students with the vocabulary and the situation presented in the text. 


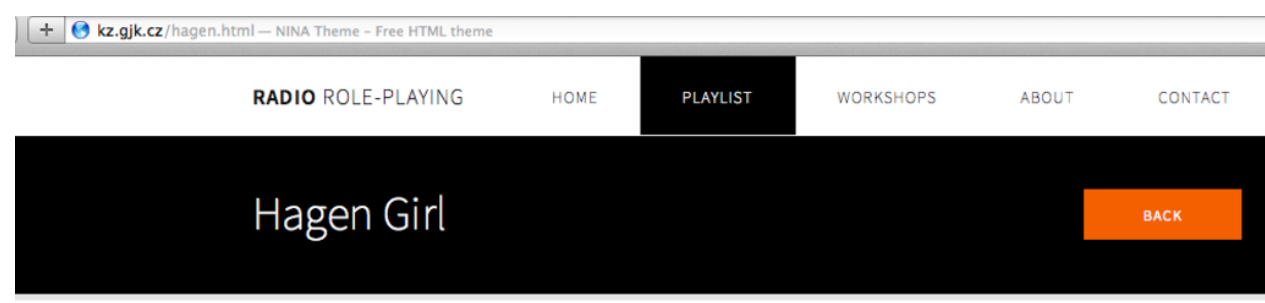

Read the text (language work, reading)

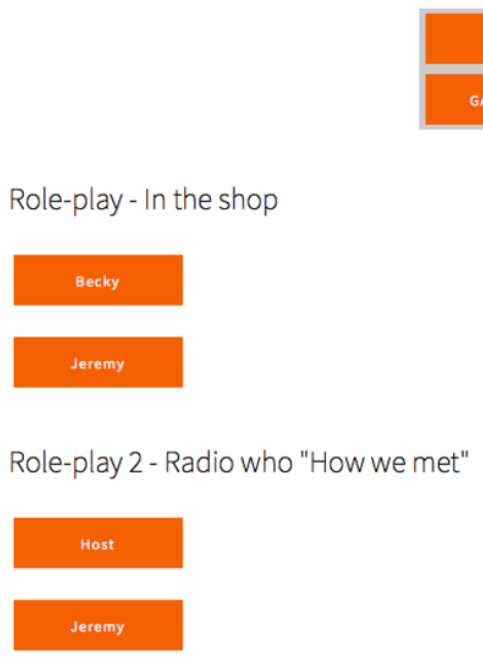

Figure 1: Graphic user interface

From text to pre-text - The teacher needs to make a transition between the input material (text) and situational context for a role-play. For achieving the transition as seamlessly as possible, the teacher must lead the students into the situational context by means of a pre-text - a short narration which will provide hints of what will follow and create feelings of expectation and curiosity to find out more by experience.

This can be illustrated using an example from the Hagen girl text. This text provides a description of a girl working at a check-out counter, narrated by a boy who goes to the grocery store every day, sees her every day and in the text expresses his thoughts and assumptions about her. Although it does not say in the text, it may be implied that the boy likes her or might even be in love with her. After a short discussion with students about the two characters (during which some students might address the boy's affection) the teacher might say something like: I'll tell you a little bit more about these two. They are Becky and Jeremy. There is a reason why Jeremy goes to see Hagen every day and, this time, the visit was different. Do you want to find out what happened?

Role-Play - Students are asked to work in pairs and decide who will play which role. Then they are asked to read their role-card. At this point students 
are given trust and responsibility not to look at the other person's role-card (the pilot version of the software does not have the functionality to prevent such an action). After the students have read the role-card they are given a brief amount of time to prepare for the role-play. Meanwhile the teacher can make sure that everyone understands what to do and can clarify the meaning of certain words in the role-cards if needed.

Then the teacher tells the students to start, or gives them a 5 second count-down so they all start simultaneously. At the word "start" students tap on the timer button "start", which will start the countdown and role-play is in progress. When the time is up, the students stop speaking.

Reflection - The students are then asked about their experience, how it went, why and what they might have done differently. It is essential to encourage students to explore other possibilities and alternative solutions. The role-play can be repeated again in the same pairs, different pairs, or one of the pairs can role-play their situation for everyone. The depth and length of reflection can vary depending on the specific educational goals.

\section{Research}

\subsection{Introduction of the pilot study}

The aim of the research part of this paper is to present the results from pilot testing the app in an educational setting and explain the subsequent, qualitative research. For the purpose of the study an html web page was designed with simple functionality, i.e. capability of displaying educational content (text, vocabulary material, role-cards) and a countdown timer for each of the role-plays.

The main objective of the testing was to explore 1) how students perceived the lesson in general; 2) if and in what aspects the students perceived the difference between paper and digital version; 3) what advantages and/or disadvantages of the digital version they noticed;

4) whether or not, and how, the use of technology changed their player experience; 5) what were students' ideas for improvement.

\subsection{Research design and methodology}

The pilot study was completed in May 2014 at Johannes Kepler Grammar School in Prague with three groups (language classes) of students aged 15-17, at levels B1-B2, with a total of 35 respondents. The study was carried out in the standard educational environment and mobile devices were not available for all the students. 23 students worked on their mobile devices (10 tablets, 12 smartphones, 1 kindle) while the remaining students (12) were provided with printed material. The devices were connected to the Internet via school Wi-Fi which proved to be slow and unstable, often resulting in slowing down the 
process of instruction. At times the low processing speed of students' devices also contributed to the delay.

All the students had previous experience with role-playing in English classes, including text and vocabulary work routines and radio role-playing technique. This enabled comparisons to be made between classes where the educational material is mediated via mobile device versus the printed version to which they were accustomed.

Research data was collected by means of a questionnaire comprising 6 open questions related to the research questions:

- Which 3 adjectives would you use to describe the lesson?

- Can you provide more details about how you perceived the lesson (optional)?

- What significant differences did you find between the paper version and the digital one?

- Can you list some advantages and disadvantages for the digital version?

- How different was the role-playing experience?

- Can you provide suggestions for improvement?

All students present in the class took part in the questionnaire research but the focus was on the students working on mobile devices. The only exception was the first question where the general evaluation was aimed at the lesson as a whole and, therefore, the answers of all students (both with and without mobile devices) were subjected to analysis and interpretation.

\subsection{Analysis and interpretation of students' questionnaires}

Students' perception of the lesson - The set of adjectives provided insight into students' general perception and evaluation of the lesson. Open coding was applied from which the following categories emerged: mood, dynamics, organization, novelty, ordinariness, drama and learning. The answers arranged in the table below (Figure 2) illustrate how different adjectives were attributed to each of the categories.

Students who used mobile technology in the class were more likely to perceive the lesson as dynamic (fun, exciting, not so boring, refreshing, crazy, entertaining, interactive, challenging), explicitly different in a positive way (new, unusual, better than always, better, nice change, more interesting) and were also more likely to refer to positive feelings (awesome, nice, comfortable, great, cool, enjoyable). There was more reference to the organization of the lesson both positive (well-prepared, well-composed, well-organised) and negative (slow, uncoordinatable, more complicated). The answers from the students who worked with printed material naturally pointed to ordinariness (ordinary, ok, 
Table 1: Distribution of answers according to categories and students with or without mobile devices

\begin{tabular}{|c|c|c|c|c|c|c|}
\hline & \multicolumn{3}{|c|}{ Positive } & \multicolumn{3}{|c|}{ Negative } \\
\hline Category & $\begin{array}{l}\text { Answers } \\
\text { given by } \\
\text { the } \\
\text { students } \\
\text { with a } \\
\text { mobile } \\
\text { device }\end{array}$ & $\begin{array}{l}\text { Answers } \\
\text { given both } \\
\text { by } \\
\text { students } \\
\text { with and } \\
\text { without } \\
\text { mobile } \\
\text { devices }\end{array}$ & $\begin{array}{l}\text { Answers } \\
\text { given by } \\
\text { students } \\
\text { with no } \\
\text { mobile } \\
\text { device }\end{array}$ & $\begin{array}{l}\text { Answers } \\
\text { given by } \\
\text { the } \\
\text { students } \\
\text { with a } \\
\text { mobile } \\
\text { device }\end{array}$ & $\begin{array}{l}\text { Answers } \\
\text { given both } \\
\text { by } \\
\text { students } \\
\text { with and } \\
\text { without } \\
\text { mobile } \\
\text { devices }\end{array}$ & $\begin{array}{l}\text { Answers } \\
\text { given by } \\
\text { students } \\
\text { with no } \\
\text { mobile } \\
\text { device }\end{array}$ \\
\hline MOOD & $\begin{array}{l}\text { awesome, } \\
\text { nice, com- } \\
\text { fortable, } \\
\text { great, cool }\end{array}$ & enjoyable & & & & \\
\hline DYNAMIC & $\begin{array}{l}\text { not so } \\
\text { boring, re- } \\
\text { freshing, } \\
\text { crazy, en- } \\
\text { tertaining, } \\
\text { interact- } \\
\text { ive, } \\
\text { challen- } \\
\text { ging }\end{array}$ & $\begin{array}{l}\text { fun, } \\
\text { exciting }\end{array}$ & $\begin{array}{l}\text { fast, } \\
\text { surprising }\end{array}$ & & stressful & $\begin{array}{l}\text { exhausting, } \\
\text { difficult }\end{array}$ \\
\hline ORGANIZATIO & $\begin{array}{l}\text { Vwell- } \\
\text { prepared, } \\
\text { well- } \\
\text { composed, } \\
\text { well- } \\
\text { organized }\end{array}$ & & well-timed & $\begin{array}{l}\text { slow, } \\
\text { uncoordinat } \\
\text { able, } \\
\text { more } \\
\text { complic- } \\
\text { ated }\end{array}$ & & chaotic \\
\hline NOVELTY & $\begin{array}{l}\text { new, } \\
\text { unusual, } \\
\text { better } \\
\text { than } \\
\text { always, } \\
\text { better, } \\
\text { nice } \\
\text { change, } \\
\text { more } \\
\text { interesting }\end{array}$ & & Different & awkward & & strange \\
\hline USUAL & good & $\begin{array}{l}\text { normal, } \\
\text { interesting }\end{array}$ & $\begin{array}{l}\text { ordinary, } \\
\text { ok, okay, } \\
\text { usual, like } \\
\text { every } \\
\text { other } \\
\text { lesson }\end{array}$ & & & \\
\hline DRAMA & $\begin{array}{l}\text { atmospheri } \\
\text { kind of } \\
\text { real, more } \\
\text { realistic }\end{array}$ & $\begin{array}{l}\text { good for } \\
\text { improvisa- } \\
\text { tion, } \\
\text { honest }\end{array}$ & & & & \\
\hline LEARNING & $\begin{array}{l}\text { learning, } \\
\text { working, } \\
\text { educa- } \\
\text { tional }\end{array}$ & & $\begin{array}{l}53 \text { seful, } \\
\text { valuable, } \\
\text { contribut- } \\
\text { ing to } \\
\text { speaking }\end{array}$ & & & \\
\hline
\end{tabular}


okay, usual, like every other lesson), as this very much reflected instruction in our usual classes. A limited scope of answers explicitly referring to drama is not surprising, as the students were focusing on words with more general and broader meaning to express feelings, mood and evaluation.

The following is a list of words which appeared in the responses more than once: fun (18), interesting (9), ordinary (3), interactive (3), exciting (3), new (3), good (3) enjoyable (2), stressful (2), well-prepared (2), comfortable (2), honest (2). Although this study does not intend to use quantitative research methods, a graphic representation of the word frequency in the students' evaluation is included to provide a clearly arranged overview (Figure 3).



Figure 2: Graphic representation of student's evaluation

Paper vs. digital - The students most frequently saw the difference in two main features of the app: timer and instant access to learning content (text, exercises, key, role-cards). According to some students, the timer helped them structure and plan the role-play, especially those who were in the role of the host, whose task it is to manage the interview and finish on time. Instant access allowed students to work at their own pace, check their answers via the key button and proceed to the next activity. There was one more aspect mentioned by several students - it is environmentally friendly. Those students who worked with mobile devices saw the lesson as more structured, organized and prepared. Below are some of the students' answers reflecting the analysis above.

"The timer changes the whole conversation, I see how much time everything takes and we can end - we can plan it somehow to fill the time." (Barbora, 15) 
"I don't have tons of small papers or I don't have to leave the classroom to hear what to talk about in my role - I can comfortably read it." (Zuzana, 15)

"I can see the key when I am ready and I don 't have to wait for the others." (Lukas, 16)

"I think that with this role-play setup I really entered my role. And I really liked all sort of tactics (of how I am supposed to approach the conversation). In it's final form it will be awesome." (George, 17)

"I really started to talk to Zun and Kryštof as to Jeremy and Becky. It gave me the experience of how to lead a radio show for 7 minutes. It's not that easy as it looked like at the beginning." (Ondřej, 16)

"Electronic version is better because you don't need to print so many papers." (anonymous)

"We save our forests! We don't have to bring any papers to class, just some device." (anonymous)

"Well, I think this play has been exceptionally great and offered really much place to enter the role and I enjoyed it. I honestly think it just feels a little bit better to read the text from display instead from paper (you know the hi-tech feeling). But except that it is exactly the same thing (= good thing)." (anonymous)

"I feel like it is much more organised. The "character profile" and task is there in front of you and you can read it through more times. You also have the timer in front of you, so you can check anytime adjusting the discussion to how much time you have left." (Antonín, 16)

Not all answers praised the digital alternative. One of the main drawbacks was poor internet connection which interrupted the flow of the lesson. Also, not all students were equipped with a mobile device and printed material had to be distributed to them. Consequently, the whole process of instruction was slower than usual and some students pointed this out in their answers. The app proved not to be suitable for smartphones; some of them were slow and struggled with the Internet connection and displaying learning content. The digital version, according to some, is not good for one's eyes and also not everybody enjoys using technology. Below are answers of two girls who preferred the paper version:

"I always like more when something is matter, I can touch it, move and have at hand or in sight and this is better with paper. Simply: when I don't need to use electronic device, I don't use it. That goes for PC or mobile phone too." (Marketa, 17)

"Obviously each of us would have to have a device. In my opinion, the less often I use a computer, the better." (Tereza, 16) 
Regarding the difference in player experience, according to the vast majority of students there has been none. Most of them answered that in principle it resembled the way role-playing is used in their usual classes and the devices did not change the experience. Two boys indicated their experience was better - they enjoyed using technology, one of them had a "high-tech feeling" (Tonda, 17).

The reason why the experience did not change for most of the students might be that the communication channels remained the same - in the actual role-play the students were communicating face to face. The electronic device only served as an information input tool and a time-keeper. What did change was their more strategic approach to fulfilling the given task within a role-play, as they could watch the count-down and plan their strategy accordingly.

More concrete and in-depth findings in the area of players' experience could be gained through interviews or focus groups, which might be advisable for future research.

Suggestions for improvement -Even a basic implementation of the app requires two main conditions to be fulfilled: a reliable Internet connection with adequate speed and a mobile device for every student. Although smartphones are functionally close or identical, they are not suitable for their size; tablets, therefore, are a much more suitable choice. There was a demand for interactivity of the app that would allow gap-filling forms with possible automatic correction (auto-check), note-making, underlining. These, however, would require a database (MySQL or similar) and would be technically more demanding to create.

\subsection{Author's observation}

The author's observation corresponds with the answers in the questionnaire. At the beginning the students seemed to be excited and were anticipating something new; most of them enjoy working with technology and this may have induced positive feelings. Some tension and excitement was lost while waiting for the learning content to display and it took much longer than anyone would have expected. Therefore, the theoretical capability of the technology to display content instantly (which was initially considered one of the greatest benefits of the app) turned out to be its most limiting aspect in this case. Despite this setback, the students seemed to be focusing more and listening more carefully to instructions, which might have been a result of the novelty aspect.

While role-playing the increased level of noise and amount of gestures that are characteristic for drama-based activities did not appear to differ from when used in regular classes. 


\section{Conclusion}

The main objective was to create a tool that would overcome some of the previous limitations in role-playing, as seen by the author. A simple app was created, whose instruction modelled the existing printed material format.

The pilot study showed that students perceive the use of digital technology for role-playing in language classes as similar to working with printed material. Most of them see both instruction methods as entertaining and enjoyable, as well as useful, especially in terms of developing their speaking skills, namely fluency and i $\mathrm{m}$ provisation. There a re several a d vantages from the students' point of view: timer, instant access to the learning content (provided the internet connection and their device are in proper working order), no printing and no paper work.

Among the main limitations is the requirement for every student to have their own tablet and reliable Internet connection (smartphones did not prove to be suitable for this purpose and perhaps should be used only as a back-up device). Apart from these limitations there is question as to whether or not the use of technology is healthy for students (or anyone) when used for an extended amount of time.

There are certainly possibilities of further development of this app. The next step would be creating a real web application that would use a database to create, modify or store the content, which would allow the users to create a teacher or a student account. Within the app a teacher would be able to make groups of users and monitor and control the content displayed on the students' devices within his or her group. Such an app would also allow teachers to assign roles to each student's device (randomly, automatically or manually) and this would prevent students from being able to explore content that is not intended for them.

The app would also allow teachers worldwide to use, add and modify teaching material and role-plays in the database within the app. Consequently, this would fulfil the in itial id ea of th e ro le-playing ki tchen - sh aring ideas, spreading inspiration and motivation to use drama based activities in language instruction.

Despite the mentioned advantages and the possibilities for future development, there are other questions to be considered, such as the extent to which the use of digital tools for learning is suitable, especially with its health implications. Another question to consider is how and to what extent the use of technology influences students' i magination and c $\mathrm{r}$ eativity. The ti me has not yet come to implement such methods due to the main obstacles (Internet connectivity and devices for everyone); therefore, I will keep working with paper while developing Role-Play Kitchen v.1.2.

\section{Bibliography}

Barab, Sasha A.; Carteux, Robert; Tuzun, Hakan (2005): Making learning fun: 
Quest Atlantis, a game without guns. In: Educational Technology Research and Development 53/1, 86-108

Brown, Douglas, H. (2001): Teaching by principles: an interactive approach to language pedagogy. White Plains, NY: Pearson Education

De Freitas, Sara I. (2006): Using games and simulations for supporting learning. In: Learning, Media and Technology, 31/4, 343-358. doi: 10.1080/17439880601021967

Dekeyser, Robert M.; Sokalski, Karl J. (1996): The Differential Role of Comprehension and Production Practice. In: Language Learning, 46/4, 613-642. doi: 10.1111/j.1467-1770.1996.tb01354.x

Di Pietro, Robert J. (1982): The Open-Ended Scenario: A New Approach to Conversation. TESOL Quarterly, 16/1, 15-20. doi: 10.2307/3586559 (Accessed 10 November 2013)

Ellis, Rod (2003) Task-based language learning and teaching. Oxford: Oxford University Press

Gee, James Paul (2003): What video games have to teach us about learning and literacy. New York: Palgrave Macmillan

Hays, Robert, T. (2005): The effectiveness of instructional games: a literature review and discussion. Technical Report 2005-004. Orlando, FL: Naval Air Warfare Center Training Systems Division

Kirriemuir, John; McFarlane Angela (2004): Literature review in games and learning: a report for NESTA Futurelab. Bristol: NESTA Futurelab

O'Neill, Cecily (1995): Drama Worlds: A Framework for Process Drama. Portsmouth, NH: Heinemann

Papastergiou, Marina. (2009): Exploring the potential of computer and video games for health and physical education: A literature review. In: Computers, 53/3, 603-622. doi: 10.1016/j.compedu.2009.04.001

Shrum, Judith L.; Glisan, Eileen W. (2009): Teacher's handbook: contextualized language instruction. Boston, MA: Heinle Cengage

Squire, Kurt (2005): Changing the game: what happens when video games enter the classroom. In: Innovate, $6 / 1$. http://www.innovateonline.info/index.php?view $=$ article\&id $=82$ (Accessed 10 July 2014)

Thornbury, Scott (1999): How to teach grammar. Harlow: Longman

Žd'árek, Karel (2013): Radio role play: the use of a simulated radio studio in TEFL. In: Scenario, 7/1, 28-43. http://research.ucc.ie/scenario/2013/01/Zdarek/03/en (Accessed 10 July 2014)

Žd'árek, Karel (2014): Role-playing Kitchen. http://kz.gjk.cz/.html (Accessed 10 July 2014) 